\title{
Boosting Motivation to Help Students to Overcome Online Learning Barriers in Covid-19 Pandemic: A Case Study
}

\author{
https://doi.org/10.3991/ijim.v15i10.20319 \\ Hong-Thu Thi Nguyen \\ Hanoi Law University, Hanoi, Vietnam \\ nguyenthihongthu2607@gmail.com
}

\begin{abstract}
In response to the public health emergency of Covid-19 pandemic, changing learning and teaching from face to face mode to online one is determined to be imperative. The fact that classrooms were temporarily prevented from continuing did not mean that learning and teaching activities were suspended. They were going on in a new approach supported by technology, which challenges students and teachers with various barriers. The paper investigates the correlation between online learning barriers and motivations, whether the motivation-boosting strategies could help students overcome challenges in online learning duration and had any impact on students' academic achievement or not. A quasi-experimental research was applied for 288 third-year students of law joining the second criminal law course at a university in Viet Nam. The experiment was conducted with the assistance of LMS, Microsoft Teams, Skype and Zoom, along with the software like Socrative, Kahoot and Social networks. The findings revealed that the extrinsic barriers had more impact on motivation than intrinsic ones; extrinsic barriers had high impact on the motivation and the learning results of students compared to the traditional learning method. The data also expressed that the motivation-boosting activities in the online learning process led positive changes in students' learning motivation and academic achievement.
\end{abstract}

Keywords - Motivation; barriers; online learning, Covid-19 pandemic, motivation-boosting activities

\section{Introduction}

The Covid-19 outbreak has tremendously affected all fields of life of which education is a seriously-suffered case. Schools and academic institutions were forced to close in an attempt to prevent the spread of the pandemic. However, policy makers asserted that school closure did not mean stopping learning and teaching. They managed to determine the appropriate solutions to maintain classrooms from home by remotely using Information and Communication Technologies (ICT). This was a temporary solution in emergency, thus the administers did not anticipate the constraints and challenges teachers and learners had to confront. Students complained 
about the lack of preparation universities should have made before for online instruction. Similarly, learners indicated that online learning was inferior to face-to-face classes [1]. Also, no one ensured the effectiveness of e-learning mode that there have ever been the skeptical opinions and arguments on. In Viet Nam, a number of elearning applications have been employed, such as Zoom, Skype, Microsoft team, LMS, FITEL, Google classroom. In Hanoi Law University, LMS and Microsoft Teams were opted to be the main systems applied in online teaching in Covid-19 season. However, teachers and learners have never had opportunities to train IT competence and skills properly and professionally. Consequently, the challenges have existed as the main barriers to students' motivation and academic achievement. In the experiment of the online teaching, Acat, M. B. \& Demiral, S. [2] investigated that students and instructors faced the barriers in learning online, however in the studies ([3], [6], [7], [8]), the authors admitted that boosting students'motivation was considered as a great effort to help students to overcome the online learning barriers and raise learning results. According to Martin, A. J. [3] "There are three things to remember about education. The first one is motivation. The second one is motivation. The third one is motivation". This illuminates the importance of motivation in the learning process. It is believed that everything can be positively changed if students are provided with enough motivation. Motivation is the core value of long-life learning and teaching. Dörnyei, Z., \& Ushioda, E. [4] recommended that the experiment of online learning could bring the value to education not only during school closure but also in the future when the Covid epidemic disappears.

With the aim of investigating students' and teachers' barriers and motivation in learning online, the study hopefully contributes to the literature on the internal and external factors affecting applying e-learning, clarifies the connection between them with the other contextual factors, and discovers the motivation-boosting strategies in learning online in the Ovid-19 pandemic. The article focuses on two research questions:

1. How did the barriers impact students and teachers' motivation in online learning during the 19-Covid pandemic?

2. How did the motivation-boosting strategies affect on students' academic achievement?

\section{$2 \quad$ Literature Review}

\subsection{Traditional and online learning approaches}

The research on online teaching approaches has recently drawn much attention and concern from the instructors and educators. Although there have still been the approvals for the traditional teaching method, an increasing number of researchers have asserted that it is imperative to change the teaching method to a more initiative one with the assistance of IT as online learning or integrate the new method into the traditional one as blended learning ([5], [6], [7]). Online learning comprises two common 
types including blended learning, which combines face-to-face and computer-based learning [8] and entirely online learning in which every learning and teaching activities are performed on Internet with the support of web-based resources and learning management systems [9]. In the blended learning mode, flipped method is typically applied with the potential online sources from other forms of multimedia before giving lectures in face-to-face classes [10]. Meanwhile, McLaughlin et al. [11] determined that MOOCs, online real-time interactive teaching, and video -based teaching are three common types of online instruction. In the process of computer-assisted teaching, teacher focuses on the active collaboration, applying knowledge in practice and real context rather than transferring knowledge, which is considered passive in learning process [11]. The main role in e-learning classroom orients from lecturer to students and the teacher becomes the facilitator. In IT-based classroom model, students' active role is placed on a more important position and acknowledge acquirement is supported by IT- assisted activities like watching web-lectures, searching information on webs, communicating and collaborating through online platforms, then applying knowledge and practicing assignments on the online assessment software, network, online community or collaborative group work (([5], [7], [12]). Zhuang Zhou [12] highly evaluated the IT-driven learning model as an effective way to optimize students' autonomous learning [13]. The presence of a teacher is just to support the learning process and help students have critical thinking to tackle situations. In short, online education has become a popular alternative to brick-and-mortar classrooms with numerous benefits for learners to participate in various asynchronous and synchronous learning activities [14].

\subsection{Barriers in online learning}

Previous studies have attempted to define barriers in different ways, one of which is widely accepted by Logan, S. \& Medford, E. [15]. They considered the difficulties and challenges in learning and teaching process as 'barriers', Classification of elearning barriers has been a major concern to educators and researchers. Consequently, there have been a wide range of learning barriers identified from the different perspectives. Ertmer [16] mentioned two sets of barriers. The first one is made up of technical facilities and support, whereas the second set of barriers is composed of pedagogy, belief or personal preferences. Another classification determined by Prober, C. G., \& Khan, S [17] encompassed material and non-material barriers. Meanwhile material barriers are related to lack of Information and Communication Technologies (ICT) resources, non-material barriers are relevant to teachers' knowledge and skills. Based on the levels, Bergmann, J., \& Sams, A. [18] grouped online learning barriers into teacher level, school level and system level. Similarly, Akbaba, S. [19] categorized e-learning barriers originating from factors such as learners, teachers, curriculum and schools. Particularly, learners could encounter the challenges emerging from inside themselves as well as the factors deriving from teachers consisting of teacher confidence, teachers' attitudes and beliefs to ICT, teachers' knowledge and experience ([9], [17]) and external barriers encompassing teaching and assessment methods, organizational and structural factors, teaching environment (([6], [7], [19]). Addition- 
ally, the conflicts in curriculum in online learning environment also hindered learners and teachers from acquiring knowledge and training. Thus, teachers were responsible for making the appropriate changes to fix the context and adjust the teaching content to the method that could struggle with the barriers to boost motivation for students. Regarding school, issuing the appropriate policies and financial support was highly appreciated. In terms of the relation between e-learning barriers with learning motivation and achievement, De Meyer et al., [20] indicated that barriers have a significant impact on e- learning implementation. Of four barriers including students, instructors, infrastructure or technology, and institutional management, infrastructure and technology is considered as the biggest obstacle whereas the factors belonging to students did not matter. Halim and Hashim [21] claimed that the barriers in online learning had bad effect on student motivation and attitude. As a result, the academic achievement was not satisfying as expected. So, educators and administrators will have to develop innovative solutions based on best practices to ensure that academic learning objectives and goals are being met. "Without knowing where the roots of motivation lie, how can be teachers water those roots?" ([22], p.15). The fact spotlighted the requirement that teachers must know the roots of motivation to raise them and before encouraging students, teachers must recognize existing problems as barriers to resolve.

\subsection{Motivation in learning and online learning}

Based on the definition of Gardner [23], highly-motivated learners have stronger desire, express more positive attitudes and make more attempts in learning to achieve the goal. This shed light on the factors of motivation, comprising what come from inside as an inner drive and social factors influencing learners' attitude from outside, called outer factors. Nurmi, J. E. \& Aunola, K. [24] revealed that motivation determines the learner's involvement in participating in classroom activities and attitude towards learning.

There has been much classification of motivation in learning. Central to this is the identification of Teoh, S. H., Koo, A. C. \& Singh, P. [25] in which motivation was divided into 2 types: internal and external. More specifically, intrinsic motivation signifies internal needs to be aware of the importance of a subject and try to be competent in a subject. In contrast, extrinsic motivation refers to external reinforcers like the teacher' appreciation. Drawing on the research findings, proper strategies, methods and techniques can be generated to enhance students' intrinsic and extrinsic motivation in which learning autonomy was an important factor ([26, [24, [27]). According to behaviourists, the physical environment and teachers' instruction were placed on the premier position in the online education environment. This highlighted the importance of external motivation factors in the learning process, which was also consented by many researchers ([28]; [7]; [25]). Meanwhile, cognitivists made an emphasis on intrinsic motivation with the aim of achieving the satisfaction in life.

Pertaining to the effect of motivation in learning online, a large number of researchers manifested that the improvement in students' level of academic achieve- 
ment partly rests with motivation ([29], [11], [22]). As Gardner [23] claimed, motivation made impact on a language learning outcome independently from language aptitude. It is, thus, evident that motivation is one of the indispensable factors driving students to the goal of learning process. This statement is also asserted by Tseng, C. H., et al. [30] that motivation in online education can improve students' attitudes towards learning.

\section{$3 \quad$ Methodology}

\subsection{Participants}

The participants involved in the study were 288 second-year students with 198 female students $(68.75 \%)$ and 90 male students $(31.25 \%)$ recruited from the second criminal law course at M Law University. These students had completed the first criminal law course in the Covid-19 pandemic duration in the first semester of 2019 and they were joining the higher-level course in the second semester of academic year 2020. The population's ages range from 20 to 23 . Students were randomly distributed to one of two groups: an experimental group (mean age: 20.68; 45 males, 99 females; $\mathrm{n}=144$ ) receiving motivation -boosting treatment in learning online or a control group learning online in the traditional method without any interference (mean age: 20.22 years; 45 males, 99 females; $\mathrm{n}=144$ ).

\subsection{Data collection instruments}

In order to collect data, the researcher conducted a set of instruments including semi-structured questionnaires, pretests and post- tests, in - depth interviews.

Semi-structured questionnaires were delivered to English students at the beginning of the "criminal law 2" course to determine the barriers and motivation of learning online. With the experience in the first course, learners had a chance to express their perspectives and reflections on the online learning process, relating to barriers and motivation. The questionnaires comprised 31 items and 5 open questions. The questionnaires were designed on five- point Likert's scale. The printed copies of the questionnaire were distributed to willing participants via face-to-face meeting and online through Gmail, Google forms (for students who had not attended the class and for foreign teachers because it was difficult to gather them together at a certain time).

Furthermore, the participants of the two groups had taken 2 types of test including pretests and post-tests to check the effect of motivation-boosting strategies on their academic achievement. The pretests were conducted at the beginning of the course to compare the input level between the control and experimental groups when there had been no intervention. The post-tests were conducted at the end of the course, with the treatment in the experimental group. The teacher scored their outcomes based on 10point Likert scale. 


\subsection{Data collection and analysis}

To collect data for this study, quantitative analysis and survey research methodology were conducted (Creswell, 2014). The data from the questionnaires were treated by means of both qualitative and quantitative approaches. The quantitative data were analyzed with the asistance of descriptive statistics IBM SPSS 25.0 software. The demographic information of the participants was referred from frequency descriptive test.

A reliability analysis was conducted as the first phase of the data analysis process. The Cronbach's alpha value $0.83(>0.7)$ indicated that this scale has a reliability [31] to continue treating the other data in the next steps (Ozkip, 2009). According to Hair et al. [32] All items had the factor loading $>0.7$, meeting the minimum threshold value of 0.70. In addition, Cronbach's Alpha, the Average Variance Explain and Composite Reliability tests for each construct were undertaken with the value $0.43>0.50$ and $0.87>0.70$, respectively [32]. These findings made a good unidimensionality validity for variables to ensure the proper data treatment for the research questions. The author used descriptive analyzing tool to calculate mean and standard deviation values of the barrier and motivation factors, to investigate the Correlation between the online learning barriers and motivation, the author analyzed Pearson and Anova, coefficients in the regression test. Then, the writer utilized Paired-sample T-test to measure the difference between motivation and academic achievement of two groups before and after being intervened with the strategies to hindrance the barriers in learning online (experimental group) and used regression test to investigate the correlation between them.

\subsection{Procedure}

At the beginning of the course "criminal law 2", the questionnaires were delivered to 288 students to accumulate data for the first research question relevant to barriers and motivation of online learning on the premise of the experience of the first course, with the assistance of LMS in Covid-19 pandemic duration. The information on students' sociodemographic characteristics, age and gender, barriers and motivation in online learning was gathered from the survey. The author used Academic Motivation Scale (AMS) of Vallerand et al. (1992) to evaluate student motivation.

In the second course, students kept learning online due to the return of Covid 19. The participants in this course were divided into 4 classes with the support of Microsoft Teams, two of which were combined into the control groups and the two classes left were distributed to the experimental groups. In the first period of the second course, all students did the same pretest based on the knowledge of the subject "criminal law 1" to measure the average scores of the two groups. In the learning process, in the control group, the teacher gave lectures on the basis of the traditional method by explaining theory and examples, giving feedback and revising the old lesson. However, in the experimental groups, teachers adjusted the syllabus orienting to practice and learning autonomy through audio news, video clips, websites, social media, e-books, text chatting, automatic writing evaluation software, voice messages, 
and video calls. The teacher used Microsoft Teams as the main teaching tool along with Skype, Zoom, and Google classroom.

Before class time, students were given textbooks of criminal laws 2 to study and prepare for a presentation such as unit 3 "The types of criminal crimes". Students were asked to work in groups of five or six to present what the class would learn and the other groups contributed to the lectures by giving comments or adding important content. During the discussion, Skype or Zoom was used to create a room for preparing the presentation and exchanging ideas among the numbers of groups. Using videos, images or clips about the cases to illustrate the theory was compulsory. Students could make the presentation in front of class or play the recordings, videos or movies they had made by themselves as an alternative for the presentation that were required to ensure the content relevant to the lesson and to be interesting. In class, the teacher gave the right of presenting to students, and student time was placed on the priority. Meanwhile teachers utilized Microsoft Teams to create many types of questions or quizzes to test students' understanding. Teachers also used Forms on the message to design the instantaneous questions for students. Forms had a function of notifying the percentage of students choosing for each option, so teachers realized whether students understand the lecture or not. In addition, the teacher applied the apps for quizzes such as Socratic and Kahoot to draw more attention from learners. Every day, students wrote portfolios and send them to the teacher through Google classroom. The teacher corrected them directly on the portfolio. Most of the time in class is mainly for discussion and interaction between students or between students with the teacher. Meeting room was created during the discussion, and the teacher divided students in to groups when necessary. After every five periods, teacher hold a mock trial or a competition related to solving the cases of the drug-related, assaults, sexual, violent and murder crimes. Each group had to propose at least 5 theoretical questions relevant to knowledge taught and giving a case for the other groups to join and solve in the roles of the judges to proceed with the prosecution, determine criminal accusation and victimization, conviction and sentencing or the roles of lawyers to protect the accused. In addition, from the beginning of the course, each group was required to create a Facebook page in the aim of propagandizing laws to everyone. On the Facebook page, students posted the knowledge, cases, quizzes about criminal law and posed the problems or cases for followers to give the best solutions. Some groups created the games for more interest. Resting with the meaningfulness, stimulation, constructiveness, and creativeness, the teacher scored and gave feedback. One of the most important online learning stages was giving comments and discussion. So, the classes were organized as the platforms for exchanging knowledge and interaction. Through social networks, teacher connected to some experts, teachers and foreign students for discussion and exchanging experience.

At the end of the course, the control and experimental groups participated in the final test, namely, post-test. The teacher gave students mark and compared the scores between the groups. 


\section{$4 \quad$ Findings}

\subsection{Online learning barriers in relationship with learning motivation}

The author used Descriptive Statistics to calculate the mean of barriers, motivation and groups of intrinsic and extrinsic barriers.

Table 1. Means of barriers and motivation

\begin{tabular}{|c|c|c|c|c|c|}
\hline & & Mean & Std. Deviation & Weighted mean & \begin{tabular}{|c|} 
Std. \\
Deviation
\end{tabular} \\
\hline & Motivation & 3,56 & ,859 & & \\
\hline \multirow{5}{*}{$\begin{array}{l}\text { Intrinsic } \\
\text { Barriers }\end{array}$} & Unwillingness to change & 2,78 & ,806 & \multirow[t]{5}{*}{3,069} & \multirow[t]{5}{*}{455} \\
\hline & Learning habit & 2,65 & ,559 & & \\
\hline & Lack of IT learning experience & 3,59 &, 880 & & \\
\hline & Learners' attitude and autonomy & 3,66 & 1,166 & & \\
\hline & $\begin{array}{l}\text { Individual knowledge, abilities and } \\
\text { skills }\end{array}$ & 2,99 & ,753 & & \\
\hline \multirow{9}{*}{$\begin{array}{l}\text { Extrinsic } \\
\text { barriers }\end{array}$} & Lack of practice & 3,21 & ,801 & \multirow[t]{9}{*}{3,275} & \multirow[t]{9}{*}{,448 } \\
\hline & Technology and internet accessibility & 2,92 & ,700 & & \\
\hline & $\begin{array}{l}\text { Lack of appropriate online learning } \\
\text { design and curriculum }\end{array}$ & 3,34 & ,749 & & \\
\hline & Learning and teaching environment & 3,49 & ,626 & & \\
\hline & Classroom management & 2,84 & ,958 & & \\
\hline & Online Working models & 3,62 & ,968 & & \\
\hline & $\begin{array}{l}\text { Conflict between knowledge and } \\
\text { Outcomes }\end{array}$ & 3,41 & ,904 & & \\
\hline & Collaboration & 3,72 & 858 & & \\
\hline & Instructors' teaching method & 3,77 & 859 & & \\
\hline
\end{tabular}

Note: $1.0-1.79$; very low $1.8-2.59$; low $2.6-3.39$ neutral; $3.4-4.19$ high; $4.2-5.0$ high

As drawn from Table 1, students' evaluation of extrinsic barriers is higher than intrinsic ones among the challenges of learning online with $M=3.275 \%, S D=.448$, and $M=3.069 \%, S D=.445$, respectively, which reveals that students kept neutral opinions on the difficulties they encountered in the online course. In addition, the low standard deviation indicates that there was a significant difference in respondents' viewpoints. In terms of intrinsic barriers, learners' attitude and autonomy take the highest rate $(M=3.66 \%, S D=1.166)$, succeeding this ranking, lack of IT learning experience $(M=3.59 \%, S D=.880)$. About the extrinsic barriers, students considered the instructors' teaching method, collaboration, online working models as the most challenging factors in progressing their learning with $M>3.5$ meanwhile technology and internet accessibility and classroom management mostly does not matter with the lowest mean values $(M<3.0)$. It is believed that teachers are the most influential entities to students' learning motivation, which is enormously important to students' achievement. Obviously, students highly appreciated the role of teaching and learning method, autonomy as well as the collaboration among students. These factors had impact and contribution to the success of achieving the academic objectives. 


\subsection{Correlation between the online learning barriers and motivation}

Anova test with Sig. value of $\mathrm{F}$ is below 0.05 , which indicates that the variables are valid and appliable for linear regression mode. As can be seen from the table, given that Sig values of $\mathrm{t}$ are smaller than 0.05 , all the items comprising motivation, intrinsic barriers and extrinsic barriers are acceptable for the linear regression model. Consequently, the correlation among the barriers and motivation is implemented and illustrated in the table. Coefficients $\mathrm{ViF}$ of the variables are less than 2, which means no multicollinearity occurs. Sig of t value expresses that the regression coefficient of the variables is $<0.05$, so these independent variables have explanatory meaning for the dependent variable, and none of them are excluded from the model.

Table 2. Correlation between the online learning barriers and motivation

\begin{tabular}{|c|c|c|c|c|c|c|c|c|}
\hline \multicolumn{9}{|c|}{ Coefficients $^{\mathrm{a}}$} \\
\hline \multirow{2}{*}{\multicolumn{2}{|c|}{ Model }} & \multicolumn{2}{|c|}{$\begin{array}{l}\text { Unstandardized Coef- } \\
\text { ficients }\end{array}$} & \multirow{2}{*}{$\begin{array}{c}\begin{array}{c}\text { Standardized } \\
\text { Coefficients }\end{array} \\
\text { Beta }\end{array}$} & \multirow{2}{*}{$t$} & \multirow{2}{*}{ Sig. } & \multicolumn{2}{|c|}{ Collinearity Statistics } \\
\hline & & $B$ & Std. Error & & & & Tolerance & VIF \\
\hline \multirow{3}{*}{1} & Motivation & $-1,236$ & ,433 & & $-2,854$ & ,005 & & \\
\hline & Intrinsic Barriers & ,301 & , 126 & , 159 & 2,390 & ,018 & ,814 & 1,228 \\
\hline & Extrinsic Barriers & 1,181 &, 128 & ,616 & 9,246 &, 000 & ,814 & 1,228 \\
\hline
\end{tabular}

Coefficients $\mathrm{ViF}$ of the variables are less than 2, so no multicollinearity occurs. Moreover, because Beta regression coefficients are higher than 0.0, all the independent variables have the one-way impact on the dependent variable. Based on the Beta values, it can be seen that extrinsic barriers have the greater impact on motivation of learning online than intrinsic barriers.

\subsection{Students' evaluation on intrinsic and extrinsic motivation}

When it comes to motivation, it can be seen from table 3 that the general motivation stands at a high level with $\mathrm{M}=3.56$ an $\mathrm{SD}=0.859$. Going into more details, intrinsic and extrinsic motivation also contributes to the students 'online learning motivation at the high rates $(M=3.65, S D=0.330$, and $\mathrm{M}=3.53, \mathrm{SD}=3.94)$. Concerning intrinsic motivation, the most restorative factor stimulating students to study is the awareness of the importance of subject, meanwhile the lowest rate belongs to the confidence in using e-learning technology. 
Table 3. Means of Intrinsic and extrinsic motivation

\begin{tabular}{|c|c|c|c|c|c|}
\hline & & Mean & $\begin{array}{c}\text { Std. } \\
\text { Deviation }\end{array}$ & $\begin{array}{l}\text { Weighted } \\
\text { Mean }\end{array}$ & $\begin{array}{l}\text { Std. } \\
\text { Dev. }\end{array}$ \\
\hline & Motivation & 3,56 & ,859 & & \\
\hline \multirow{7}{*}{$\begin{array}{l}\text { Intrinsic } \\
\text { motivation }\end{array}$} & The need to learn & 3,78 & ,711 & \multirow{7}{*}{3,65} & \multirow{7}{*}{,330 } \\
\hline & Personal interest and joy & 3,77 & 666 & & \\
\hline & Expectation & 3,46 & ,646 & & \\
\hline & Self-esteem & 3,75 & ,743 & & \\
\hline & The awareness of the importance of subject & 4,01 & ,775 & & \\
\hline & Confidence in using e-learning technology & 3,37 & ,697 & & \\
\hline & Learning autonomy & 3,44 & ,883 & & \\
\hline \multirow{11}{*}{$\begin{array}{l}\text { Extrinsic } \\
\text { motivation }\end{array}$} & The teacher\& students' appreciation & 3,44 & ,707 & \multirow{11}{*}{3,53} & \multirow{11}{*}{,394 } \\
\hline & Convenience in communication/interaction & 3,02 & ,704 & & \\
\hline & School rules and disciplines & 3,34 & ,749 & & \\
\hline & Grading/rewards & 3,49 & ,637 & & \\
\hline & Convenience in achieving the academic objectives & 3,28 & 890 & & \\
\hline & Classroom atmosphere/learning environment & 3,64 & ,936 & & \\
\hline & Interesting lessons & 3,46 & ,852 & & \\
\hline & Saving time & 3,76 & ,802 & & \\
\hline & Being good for publishing/storing materials & 3,78 & ,829 & & \\
\hline & Innovation in teaching method & 3,85 & ,748 & & \\
\hline & $\begin{array}{l}\text { Being easy to approach diversity in online } \\
\text { knowledge source }\end{array}$ & 3,78 & 815 & & \\
\hline
\end{tabular}

Note: 1.0-1.79: very low 1.8-2.59: low 2.6-3.39: neutral; 3.4-4.19: high; 4.2 - 5.0: very high

Regarding the extrinsic motivation, most respondents were in high agreement with the motives for working hard, including innovation in the teaching method; being good for publishing/storing materials; being easy to approach diversity in an online knowledge source and saving time. Besides, Grading and teacher and students' appreciation encouraged learners to have more motivation in learning. Students were skeptical and unsure $(\mathrm{M}<3.39)$ about the motivation factors such as convenience in communication, school rules and disciplines, convenience in achieving the academic objectives because they did not get many benefits from this online learning method. Besides, the high standard deviation ( $\mathrm{SD}>0.7$ ) signifies that there were few differences in participants' viewpoints.

\subsection{Correlation between intrinsic motivation, extrinsic motivation and overall motivation}

The Sig. value of F in Anova test is below 0.05, which indicates that the variables are valid and appliable for linear regression mode. As can be seen from the table, given that some sig values of $t$ are smaller than 0.05 , all the items comprising Motivation, Intrinsic Barriers and Extrinsic Barriers are acceptable for the linear regression model. Consequently, the correlation among the barriers and motivation is implemented and illustrated in the table. 
Paper-Boosting Motivation to Help Students to Overcome Online Learning Barriers in Covid-19...

Table 4. Correlation between Intrinsic Motivation, Extrinsic motivation and overall motivation

\begin{tabular}{|l|c|c|c|c|c|c|c|}
\hline \multicolumn{1}{|c|}{ Model } & \multicolumn{2}{|c|}{$\begin{array}{c}\text { Unstandardized } \\
\text { Coefficients }\end{array}$} & $\begin{array}{c}\text { Standardized } \\
\text { Coefficients }\end{array}$ & \multirow{2}{*}{$\boldsymbol{t}$} & \multirow{2}{*}{ Sig. } & \multicolumn{2}{|c|}{ Collinearity Statistics } \\
\cline { 2 - 4 } \cline { 7 - 9 } & $\boldsymbol{B}$ & Std. Error & Beta & & & Tolerance & VIF \\
\hline Overall motivation & $-1,690$ &, 651 & & $-2,594$ &, 010 & & \\
\hline Intrinsic motivation &, 481 &, 192 &, 196 & 2,507 &, 013 &, 757 & 1,322 \\
\hline Extrinsic motivation &, 958 &, 161 &, 466 & 5,950 &, 000 &, 757 & 1,322 \\
\hline
\end{tabular}

Coefficients $\mathrm{ViF}$ of the variables are less than 2, which means no multicollinearity occurs. Sig of $\mathrm{t}$ value expresses that the regression coefficient of the variables is $<0.05$, so these independent variables have explanatory meaning for the dependent variable, and none of them are excluded from the model. Moreover, because Beta regression coefficients are above 0.0 , all the independent variables have the one-way impact on the dependent variable. Based on the Beta values, it can be seen that Extrinsic motivation has the greater impact on motivation for learning online than intrinsic barriers.

\subsection{Comparison between student-engaged time of control and experimental groups}

On investigating the student-engaged time of the control and experimental groups, the results from Paired Samples Test came out that the students in the experimental group $(M=41,43, S D=3,134)$ spent more time joining an online classroom than the students in the control group $(\mathrm{M}=39,63, \mathrm{SD}=2,245)$ with the mean deviation=1.799.

Table 5. Comparison between the student-engaged time of the control and experimental groups

\begin{tabular}{|c|c|c|c|c|}
\hline & Mean & $\mathbf{N}$ & Std. Deviation & Std. Error Mean \\
\hline Student-engaged time of control group & 39,63 & 288 & 3,134 &, 185 \\
\hline Student-engaged time of experimental group & 41,43 & 288 & 2,245 &, 132 \\
\hline
\end{tabular}

\begin{tabular}{|c|c|c|c|c|c|c|c|c|}
\hline & \multicolumn{5}{|c|}{ Paired Differences } & \multirow{3}{*}{$\mathbf{t}$} & \multirow{2}{*}{\multicolumn{2}{|c|}{$\underset{\text { (2-tailed) }}{\text { Sig. }}$}} \\
\hline & \multirow[t]{2}{*}{ Mean } & \multirow{2}{*}{$\begin{array}{c}\text { Std. } \\
\text { Devia- } \\
\text { tion }\end{array}$} & \multirow{2}{*}{$\begin{array}{l}\text { Std. } \\
\text { Error } \\
\text { Mean }\end{array}$} & \multicolumn{2}{|c|}{$\begin{array}{l}\text { 95\% Confidence } \\
\text { Interval of the } \\
\text { Difference } \\
\end{array}$} & & & \\
\hline & & & & Lower & Upper & & & \\
\hline $\begin{array}{l}\text { Student-engaged time of control and } \\
\text { experimental groups }\end{array}$ & $-1,799$ & 3,746 &, 221 & $-2,233$ & $-1,364$ & $-8,147$ & 287 & ,000 \\
\hline
\end{tabular}

The upper and lower difference showed in the figure are 2,233 and 1,364 respectively. As illustrated in the table, there is a slight difference between participation time between the control and experimental groups with a two-tailed test of significance < 0.05 . the scores were weakly correlated $(\mathrm{t}=8.147)$. Overall, the Ho hypothesis that 
there is no difference between the student-engaged time of the control and experimental groups was rejected.

\subsection{Comparison between academic achievement of the control and experimental groups}

The author Used Paired -Sample test to test the hypothesis "there is no difference between the academic achievement between two group after the interference of the motivation-boosting activities. From the results of Paired Samples Test, it can be seen that pretest scores of control and experimental groups do not indicate any difference due to the Sig (2-tailed) value $=1.0>0.05$. This illustrates an input balance between two groups to ensure conducting the post-test with the treatment of the strategies. Shedding a light onto the pretest and post-test Scores of the control group, the results are not significantly different and the correlation is weak. In contrast, there is a slight difference between the pretest and post-test Scores of the experimental group with a two-tailed test of significance $<0.05$ and the scores are weakly and positively correlated $(t=71)$.

Table 6. Comparison between academic achievement of the control and experimental groups

\begin{tabular}{|c|c|c|c|c|c|c|c|c|}
\hline & \multicolumn{5}{|c|}{ Paired Differences } & \multirow{3}{*}{$\mathbf{t}$} & \multirow{3}{*}{ df } & \multirow{3}{*}{$\underset{\text { (2-tailed) }}{\text { Sig. }}$} \\
\hline & \multirow[t]{2}{*}{ Mean } & \multirow[t]{2}{*}{$\begin{array}{c}\text { Std. } \\
\text { Deviation }\end{array}$} & \multirow{2}{*}{$\begin{array}{l}\text { Std. } \\
\text { Error } \\
\text { Mean }\end{array}$} & \multicolumn{2}{|c|}{$\begin{array}{l}\text { 95\% Confidence } \\
\text { Interval of the } \\
\text { Difference }\end{array}$} & & & \\
\hline & & & & Lower & Upper & & & \\
\hline $\begin{array}{l}\text { Pretest Scores of control and } \\
\text { experimental groups }\end{array}$ & ,000 & 1,101 & ,130 & ,259 & ,259 & ,000 & 287 & 1,000 \\
\hline $\begin{array}{l}\text { Pretest and post-test Scores of } \\
\text { control groups }\end{array}$ & ,389 & 1,193 & ,141 & ,108 & 669 & 2,765 & 287 & ,007 \\
\hline $\begin{array}{l}\text { Pretest and post-test Scores of } \\
\text { experimental groups }\end{array}$ &, 861 & 1,407 & ,166 & ,530 & 1,192 & 5,192 & 287 & ,000 \\
\hline $\begin{array}{l}\text { Post-test Scores of control and } \\
\text { experimental groups }\end{array}$ & ,472 & 1,321 & ,156 & , 162 & ,783 & 3,033 & 287 & ,003 \\
\hline
\end{tabular}

On average, post-test scores are points higher than pretest scores (1.192 and 0.530). Similarly, post-test scores of the control and experimental groups make a slight difference due to the Sig. value $<0.05$. Obviously, the average scores of the control group are lower than that of the experimental group (0.162 and 0.783$)$. In other words, with the interference of the motivation- boosting treatment, the students from experimental groups made a positive progress in academic achievement with the higher average scores in comparisons with the group without any treatment. In short, the hypothesis that there is no difference between intrinsic and extrinsic motivation and academic achievement was rejected. This conclusion coincides with the findings of Gardner (1972), Wigfield and Wentzel (2007) (as cited in Bernard, 2010) that motivation can influence language learning outcomes independently from language aptitude. It is thus evident that motivation is one of the indispensable factors driving online learning process. 


\section{Discussion}

On the premise of the correlation between the barriers and motivation in learning online, the findings elucidated the impacts of barriers on online learning motivation, among which extrinsic barriers were determined to be more challenging than intrinsic barriers. In other words, the problems of online learning mostly derived from teachers, schools, curriculum and learning environment, of which the factor "instructor's teaching method" was ranked the first. This finding coincides with the investigation of Pintrich, P. R. \& Schunk, D. H. [26] on the influences of extrinsic barriers on learner motivation. In the same way, Masitsa, G. [22] and Zhuang Zhou [12] were also in agreement and provided a more detail description of the barriers embracing the lack of online learning environment; instructors' innovative teaching methods; lack of elearning skills and competence; teachers' attitudes and beliefs to ICT; and suitable assessment ([8], [10]; [18]). This illuminates the importance of teachers that is defined a core value of learning online in which they play roles as both online instructors and learners. In the role of online instructors, teachers must take charge of the work of a technician, an instructor, an inspirator, and an innovative educator who actively make positive changes, adapt and reform the curriculum to be applicable in the new learning environment. Reality has shown that once teaching-assisting tools become complex, lectures cannot be too simple and monotonic, it needs more creation and innovation. In e-learning classroom, instructors must be aware that the burden they are bearing is twofold. Besides, when situated at the position of an online learner, the teacher will understand and share students' intrinsic barriers like the need, the expectation and feeling. With the enthusiasm, a teacher might anticipate what learner think, what challenges they are encountering and what are the dos and don'ts to support them to overcome the difficulties. By and large, the participants exhibited their assent to the vital role of teacher in e-learning and made an emphasis on reforming teaching methods in online education.

With respect to the impacts of the motivation on the class involvement, the findings reflected a fact that with the intervention of the motivation-boosting strategies, it was found that there was a remarkable difference in spending time on lectures between members of the control and experimental groups. An increasing amount of participation time in an online classroom appeared in the experimental groups. This investigation can be explained that regardless the online or traditional classroom, the treatment of stimulus has the positive impacts on the students' motivation, attitude and achievement. This finding is in accordance with the researchers' studies ([21; [27]]). Stemming from the experience of online teaching, the author recognized that students are mostly willing and very eager to participate in the class activities if the lectures are innovated with the assistance of IT tools to adapt teaching methodology to course design in e-learning environment, if they have a chance to freely access to the unlimited knowledge source on internet, make and restore their own products on Apps and show their capabilities, if they can work in groups and interact with the foreign people or experts on live stream, if they are given the prompt positive feedbacks and if there is an appropriate assessment approach ([22], [24], [31]). Thanks to this interference, 
students will be able to have more motivation to keep the good spirit for long-lasting learning. It is not surprising to say that teaching is an art and teacher is an artist.

Pertaining to the academic achievement in relationship with motivation, the findings demonstrated that motivation exerted slight positive influences on students' learning results. With the support from IT and teaching innovation, the students in experimental groups had more motivation and higher scores than those in the control groups. Much recent research has consistently shown that the increase in students' motivation for learning has a close correlation to academic success (30). In an attempt to provide an explanation for these data, it can be seen that to some certain extent, the relation between motivation and academic outcomes dependently existed. There is a consensus that when having high motivation, students will spend more time investigating and exploring unknown knowledge, take more interest, pursue their passion and make more effort to get academic goals. Normally, the students who have level of motivation can achieve high academic success, and similarly, the students who have a low level of motivation will make a low level of academic performance, of course, except for the special circumstances. Even though receiving the high or low achievements rests with many factors, the attempts can offer much contribution to learning results in some ways ([29]; [25]). This finding illuminates the importance of motivation in the learning process. Indeed, whether a learner possesses a potential capability or not, learning a foreign language still requires an enormous amount of effort and patience.

In the experience of teaching online in two courses, the teachers who were interviewed about the recommendation and suggestion for online teaching revealed that in new education environment, both students and teachers have to make efforts to make appropriate changes. Students have to reinforce their learning autonomy and teachers have to increase more creativeness and innovation in each lecture. It is better for students to combine the compulsory learning management systems administered by school with the other software and IT tools in the aim of assuring that the learning process runs smoothly and students have various ways to interact and collaborate. The followings are the IT tools teachers can apply in their teaching as the effective technology supports: Filmora 8.2.2, dobe Premier, Youtube, Window Movie Maker, iMovie for recording; Microsoft OneNote, Google earth VR, Flyover for joining local virtual field trips outside classroom; Social network like Face book, Zalo, Intagram, twitter for exchanging knowledge, experience and organizing social activities; Skype, Moodle, Soundtrap, Class craft, zoom, Newsela, Pear Deck, Facebook, Padlet, Microsoft teams for collaborative learning; Moodle, Vclass, Teachertube, Haikuteds, Teded for online lecturing systems; Google drive, Google classroom, FlowVella, Flipgrid, Stixy, Google groups for active learning; Word Mover, Vclass, Quizizz, Newsela, Google form, Classjodo, Plicker for assessment and competition.

\section{Conclusion}

The study investigated barriers and motivation in e-learning in Covid-19 pandemic. Drawing on the research findings, it is concluded that in an online classroom, the 
motivation of male and female students did not make any difference in average. However, consideration about gender in teaching should be concerned because the characteristics, psychological factors, the ability of each gender often create different barriers and motivation in leaning process. Concerning barriers of online learning, students' evaluation of extrinsic barriers is higher than intrinsic ones among the challenges they encountered in the course. It seems that the IT skills and confidence in using high tech did not matter with the students. I must say that most students nowadays are excellent at IT. They are the technicians who support teacher much in the teaching process. When having any problem, it is students who help teacher fix and solve them, not IT assistants from school. In the light of the correlation between barriers and motivation, it can be seen that extrinsic barriers have the greater impact on motivation of learning online than intrinsic barriers. With regard to intrinsic motivation, the most restorative factor stimulating students to study is the awareness of the importance of subject and instructors' teaching methods, meanwhile the lowest rate belongs to the confidence in using e-learning technology. Regarding the extrinsic motivation, most respondents were in high agreement with the stimulation for working hard, including innovation in the teaching method; being good for publishing/storing materials; being easy to approach diversity in an online knowledge source and saving time. Besides, grading and teacher and students' appreciation encouraged learners to have more motivation in learning. On the basis of descriptive data, it can be seen that extrinsic motivation has the greater impact on overall motivation of learning online than intrinsic barriers. On close investigation into the effects of motivationboosting strategies, there is a difference between the participation time of the control and experimental groups. The students in the online classroom with the changes in teaching methods spent more time engaging in class than the students of the other groups. Similarly, with the interference of the motivation-boosting treatment, the students from experimental groups made a positive progress in the academic achievement with the higher average scores in comparisons with the groups without any treatment.

\section{$7 \quad$ References}

[1] Bahk, E.-J. (17 March 2020b). Colleges poorly prepared for online lectures. The Korea Times. https://www.koreatimes.co.kr/www/nation/2020/03/181_286316.html

[2] Acat, M. B. \& Demiral, S. (2002). Turkiye'de yabanci dil ogreniminde motivasyon kaynaklari ve sorunlari [Sources of motivation in learning foreign language in Turkey]. Kuram Ve Uygulamada Egitim Yonetimi, 31, 312-329. https://doi.org/10.14527/kuey. $\underline{2014.005}$

[3] Martin, A. J. (2001). The student motivationscale: A tool for measuring and enhancing motivation. Australian Journal of Guidance and Counselling, 11, 11-20.

[4] Dörnyei, Z., \& Ushioda, E. (2011) Teaching and researching motivation (2nd ed.). Harlow, UK: Pearson education limited.

[5] Bonnes et al., (2017). Flipping the quality improvement classroom in residency education. Academic Medicine, 92(1), 101-107. https://doi.org/10.1097/ACM 
[6] Gardner, R. C. (1985). Social psychology and second language learning: The role of attitudes and motivation. London: Edward Arnold Publishers.

[7] Cavas, P. (2011). Factors affecting the motivation of Turkish primary students for science learning. Science Education International, 22(1), 31-42.

[8] Garrison, D. R., \& Kanuka, H. (2004). Blended learning: Uncovering its transformative potential in higher education. Internet and Higher Education, 7(2), 95-105. https://doi.org/ 10.1016/j.iheduc.2004.02.001

[9] Yongjiang Zhang, "Development of WebGL-based Virtual Teaching Platform for Mold Design," International Journal of Emerging Technologies in Learning (iJET), 13(6), 2018. https://doi.org/10.3991/ijet.v13i06.8581

[10] Che Ghani Che Kob, Kannapiran, Shangeetavaani and A. Shah (2020). "The Usage of Mobile Learning: Comparative Studies among Technical and Vocational Education Students in Selected Universities," International Journal of Interactive Mobile Technologies, 14 (5), 203-209. https://doi.org/10.3991/ijim.v14i05.13355

[11] McLaughlin et al. (2014). The flipped classroom: A course redesign to foster learning and engagement in a health professions school. Academic Medicine, 89(2), 236-243. https://doi.org/10.1097/acm.0000000000000086

[12] Zhuang Zhou. (2018). An Interaction Theory-based New Distance Teaching Model for Cross Talk, International Journal of Emerging Technologies in Learning (iJET). 13(06), 168-180. https://doi.org/10.3991/ijet.v13i06.8588

[13] Papadakis, S. (2020). Tools for evaluating educational apps for young children: a systematic review of the literature. Interactive Technology and Smart Education, Vol. ahead-ofprint No. ahead-of-print. https://doi.org/10.1108/ITSE-08-2020-0127

[14] Fageeh, A., \& Mekheimer, M. A. A. (2013). Effects of Blackboard on EFL academic writing and attitudes. JALT CALL Journal, 9(2), 169-196. https://files.eric.ed.gov/ fulltext/ EJ1107985.pdf. https://doi.org/10.29140/jaltcall.v9n2.154

[15] Logan, S. \& Medford, E. (2011). Gender differences in the strength of association between motivation, competency beliefs and reading skill. Educational Research, 53(1), 8594. https://doi.org/10.1080/00131881.2011.552242

[16] Ertmer, P. A., \& Newby, T. J. (1993). Behaviorism, cognitivism, constructivism: Comparing critical features from an instructional design perspective. Performance Improvement Quarterly, 6(4), 50-72. https://doi.org/10.1111/j.1937-8327.1993.tb00605.x

[17] Prober, C. G., \& Khan, S. (2013). Medical education reimagined: A call to action. Academic Medicine, 88(10), 1407-141. https://doi.org/10.1097/acm.0b013e3182a368bd

[18] Bergmann, J., \& Sams, A. (2012). Flip YOUR classroom reach every student in every class every day library of congress cataloging-in-publication data. https://doi.org/ $\underline{10.1111 / \text { teth. } 12165}$

[19] Akbaba, S. (2006). Egitimde motivasyon [Motivation in education]. Kazim Karabekir Egitim Fakultesi Dergisi, 13, 343-361.

[20] De Meyer et al., (2013). Does observed controlling teaching behavior relate to students' motivation in physical education? Journal of Educational Psychology. Advance online publication. http://doi.org/10.1037/a0034399

[21] Halim, M. S. A. A., \& Hashim, H. (2019). Integrating web 2.0 technology in ESL classroom: A review on the benefits and barriers. Journal of Counseling and Educational Technology, 2(2), 1-8.

[22] Masitsa, G. (2008). Tracing the development of poor student motivation and performance in township secondary schools. Africa Education Review, 5(1), 84-108. https://doi.org/10. $\underline{1080 / 18146620802144826}$ 
[23] Gardner, R. C. (1985). Social psychology and second language learning: The role of attitudes and motivation. London: Edward Arnold Publishers.

[24] Nurmi, J. E. \& Aunola, K. (2005). Task-motivation during the first school years: a personoriented approach to longitudinal data. Learning and Instruction, 15(2), 103-122. https:// doi.org/10.1016/j.learninstruc.2005.04.009

[25] Teoh, S. H., Koo, A. C. \& Singh, P. (2010). Extracting factors for students' motivation in studying mathematics. International Journal of Mathematical Education in Science and Technology, 41(6), 711-724. https://doi.org/10.1080/00207391003675190

[26] Pintrich, P. R. \& Schunk, D. H. (1996). Motivation in education: theory, research and application (2nd ed.). Englewood Cliffs, NJ: Merrill Company.

[27] Alam, M. T. \& Farid, S. (2011). Factors affecting teachers' motivation. International Journal of Business and Social Science, 2(1), 298-304.

[28] Moffett, J. (2015). Twelve tips for "flipping" the classroom. Medical Teacher, 37(4), 331336. https://doi.org/10.3109/0142159x.2014.943710

[29] Pazilah, F. N., Hashim, H., \& Yunus, M. M. (2019). Using technology in ESL classroom; Highlights and chalnenges. Creative Education, 10, 3205-3212. https://doi.org/10.4236/ce. 2019.1012244

[30] Tseng, C. H., Tuan, H. L. \& Chin, C. (2009). Investigating the influence of motivational factors on conceptual change in a digital learning context using the dual-situated learning model. International Journal of Science Education, 10(3), 23-40. https://doi.org/10.1080/ $\underline{09500690903219156}$

[31] Papadakis, S., Kalogiannakis, M., Sifaki, E., \& Vidakis, N. (2018). Evaluating Moodle use via Smart Mobile Phones. A case study in a Greek University. EAI Endorsed Transactions on Creative Technologies, 5(16).

[32] Hair, J. F., Black, W. C., Babin, B. J., Anderson, R. E., \& Tatham, R. L. (2006). Multivariate data analysis (Vol. 6). Upper Saddle River, NJ: Pearson Prentice Hall.

[33] Vallerand, R.J., \& Bissonnette, R. (1992). Intrinsic, extrinsic, and amotivational styles as predictors of behavior: A prospective study. Journal of Personality, 60(3), 599-620. https:// doi.org/10.1111/j.1467-6494.1992.tb00922.x

\section{Author}

Hong-Thu Thi Nguyen is from Hanoi Law University, Hanoi, Vietnam. Email: nguyenthihongthu2607@gmail.com

Article submitted 2020-12-05. Resubmitted 2021-03-02. Final acceptance 2021-03-02. Final version published as submitted by the authors. 